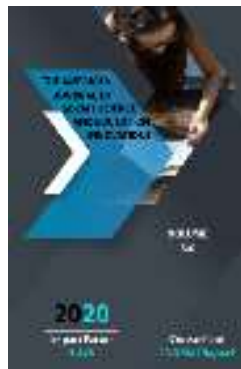

Journal Website: http://usajournalshub.c om/index,php/tajssei

Copyright: Original content from this work may be used under the terms of the creative commons attributes 4.0 licence.

\section{The Phenomena Of Semantic Widening And Narrowing In "Hibatul-Hakayik"}

\section{Bakhtiyor Abdushukurov}

Associate Professor, Tashkent State University Of Uzbek Language And Literature Named After Alisher Navoi, Uzbekistan

Lutfulla Sindorov

PhD Student, Jizzakh State Pedagogical Institute, Uzbekistan

\title{
ABSTRACT
}

The article analyzes the types of lexemes used in the work "Hibatul-Hakayik" according to the change of meaning: words with a narrowing of the semantic structure, as well as words with an expansion of meaning.

\section{KEYWORDS}

Ahmad Yugnaki, “Hibatul-Hakayik”, narrowing of meaning, expansion of meaning, internal source, external source, sema, lexeme, lexical unit.

\section{INTRODUCTION}

The lexical meaning of a word determines that it is a basic unit of the lexical-semantic system of language. However, not all words have a lexical meaning. Therefore, in Uzbek linguistics, the term lexeme is used to refer to words that have a lexical meaning in order to distinguish between words that have a lexical meaning and those that do not, and to distinguish the names of language and speech phenomena. Hence, the basic unit of the lexical-semantic system of language is a lexically meaningful word or lexeme [1, p. 31]. Lexical meaning is always part of the semantic structure of a particular word. The word has 
both a grammatical meaning and a meaning that expresses the speaker's attitude toward his speech. But these alone cannot be lexical. A lexically meaningful word serves as a part of speech, as well as conveying the meaning of morphological categories, emotionalexpressive, and stylistic meanings [2, p. 47].

\section{RESULTS AND DISCUSSION}

Although the lexical meaning of the word is more stable, it changes over the years under the influence of certain factors: 1) extralinguistic factors - socio-economic life, development of consciousness, thinking; 2) Linguistic factors - the relationship of language units within the language system [3, p. 21]. Consequently, the change of word meanings is a diverse and complex process. In particular, the narrowing, widening, and acquisition of new semantics of lexeme meaning are the product of a long period of time. In this sense, the lexemes used in "Hibatul-Hakayik" can be divided into two groups according to the change of meaning: a) words in which the semantic structure has narrowed; b) words with an expanded meaning.

1. Words with a narrowing in the semantic structure. Narrowing of meaning is the transition of meaning, which first represents a wide range of reality, to a narrow range of reality [4, p. 67]. In the narrowing of the lexical meaning, certain parts of the referent he expresses are differentiated and called by another name. As a result, the lexical meaning of the word narrows [5, p. 113]. In a number of lexemes in the dictionary of the monument under study, there was a phenomenon of semantic narrowing, that is, certain semantics of words came out of consumption. Including,

In the language of the work, the term ürün means "white": Rasullar örün yüz ol ol yüzrä kün [6, 1972]. This word first appears in the Tonyuquq monument: Sarïğ altun ürün kümüš yellow - gold, white - silver (Ancient Turkic dictionary, 627) Yusuf Khos Hajib in his epic "Qutadgu bilig" expressed the meanings of "white", "pure": Saqalïn ürün boldï keldi ölüm - If your beard is white, consider that death has come (Ancient Turkic dictionary, 627).

Although the adjective aq is not used in the epic, it was first used in "Irq bitig - Race note" to mean "gray " (noun category): Aq bisi qulunlamiiš -gray beans were used. This lexical unit in the Turfan texts literally means "positive, desirable, positive": Aq qiišin az There is little to do that pleases man (Ancient Turkic dictionary, 48). In Mahmud Kashgari's dictionary, while retaining the original meaning of the word, a new "white" sema develops: Aq bulut (MK, I,258).

So, it turns out that in the ancient Turkic language, the semantic "white" was represented by ürün lexeme. The aq qualities have been used in the same sense since the 11 th century.

Ağu monumental inscription and Uyghur documents from the Berlin collection express the meaning of "poison," "to be poisonous, poisonous": Sizlärdä almiš ağu... - poisoning from you (Ancient Turkic dictionary, 24). The first meaning of the lexeme is noted in the source under study: Yoqmaqqa (yoqamaqqa) yumšaq iči pur ağu. This word is made up of $-\mathbf{u}$ forms of the suffix a:ğ- with the verb -ï, which means "poisoning" in the ancient Turkic language (Etymological dictionary of the Uzbek language, I, 267).

The concept of "knowledge" was first introduced in the Ash tag with the knowledge lexeme (Etymological dictionary of the Uzbek language, I, 50) formed from the bil verb, 
which means "gaining knowledge and experience" with the affix --(i)g (Etymological dictionary of the Uzbek language, I, 50): Ayïg bilig anta öyür ermiš - - they learned bad knowledge from there (Ancient Turkic dictionary, 99). The lexeme continues its original meaning in "Devonu Lugatit Turk": Ula bolsa yol azmas, bilig bolsa söz yazmas - If there is a sign, a person does not go astray, if there is knowledge, a person does not err in words (MK, I, 108). Mahmud Kashgari also shows the meanings of the word "intellect, understanding", "wisdom" (I, 367): Bilig kiši ara ülüglüg ol - intelligence is distributed among humans (Ancient Turkic dictionary, 100). In documents written in Uyghur script in the Berlin collection, the fourth meaning of the lexical unit, "caution", occurs: Yiti biligin yarmï̌ kergäk - the wound should be opened very carefully (Ancient Turkic dictionary, 100). In the language of the epic, bilig lexeme mainly serve to mean the semantics of "knowledge": Bilig bildürür ergä bilig qadrïnï. At the same time, the following example shows that this term has played a key role in the formation of new words: Biliglig biligsiz qačan ten bolur.

The lexeme tarïg (NF, 188a17) first expressed the concept of "grain, seed" in the UrhunYenisei sources: Tarïğ bišdi yaš ot ündi yïlqïqa kišikä esgü boltï - the grain ripened, the green grass floured, and it was good to cattle and people (SES, 537). Mahmud Kashgari admits that the word means "wheat" in most Turkic tribes and "tariq" in Oghuz, that is, "a grain plant that can be used to whiten the grain" (MK, I, 354). In the epic "Kutadgu Bilig" it means "farming": Tarïğči tarïğda erik bolsun let the farmer show his zeal in farming (Ancient Turkic dictionary, 536). In the epic, tarïg phonetic forms are used in the semantic "grain": Tarïğliqqda qatïlan tarïğ ezgülük. It can also be observed in this example that the term was the basis for making a new word. Hence, the sememe "grain, seed" of tarïğ noun is considered a denotation for others. In later times, this meaning of the word disappeared from consumption, only the "tariq" sema remained. The lexical unit is made up of the - $\breve{g}$ affix with the tari- verb, which means "to sow" in the ancient Turkic language (Etymological dictionary of the Uzbek language, I, 322).

In Mahmud Kashgari's dictionary, qari lexemesmean "a measure of the length of an arm", "a measure of gray, gas" (III, 242). In "Tafsir", the initial meaning of the word under investigation is as follows: Ul adamnïn iki yüz qarï bu yüklüki ärdi (38b13). Uyghur legal documents of the XII-XIV centuries and in the work "Hibatul Haqiq" the semantic term "measurement of arm length" is mentioned: ... yüz eki bağlï̆ uzun qarïta böz alï - take one hundred two-bonded material (gray) of the same size as the old one in length (Ancient Turkic dictionary, 426); Qarïğa qonar ham qafasqa kirür. Qarï in the XIX century in Khorezm was $148.94 \mathrm{~cm}$, in Bukhara $320.04 \mathrm{~cm}$, in Fergana $164.45 \mathrm{~cm}$. In Tashkent, there are two types, the first of which is the market age $177.8 \mathrm{~cm}$, the second khan age $-213.36 \mathrm{~cm}$ [7, p. 118]. The word is originally formed with -ï affixes, meaning "the part of the hand from the shoulder to the elbow," which means to shrink from qar noun. In the Uzbek language, the vowel a is replaced by ä vowels, the hardness of $\ddot{i}$ vowels is lost: qar $+\ddot{i}=$ qarï>qäri (Etymological dictionary of the Uzbek language, I, 525).

The word köl in Turfon texts means "a place where water collects, a lake": Quğu quš učtï kölingä qonmas - the swan flew away without landing in its lake (Ancient Turkic dictionary, 313). In Devon it means: "pool", "accumulated water, lake"; "Sea": köl köpügi (MK, III, 148149). In the study note, the lexeme has a main (denotative) meaning, "a place where water 
collects, a lake": Ya māydan tek ol gul karam al köl ol.

Ancient Turkic language sources, such as the work "Golden Light", monumental inscriptions and Turfan texts, express the qatigg qualities of "hard" (DTS, 433), "harsh, ruthless" (SES, 433), "strong" semantics: Adawaki yekqatïğ ünin qiïiirïb - Adawaki cried out in a loud voice (SES, 433). In the memoirs of the Karakhanid period, "hard": Ol qatïğ nejni yumšattï - he softened the hard thing; "Cruel, ruthless": Azunta negü bar ölümdin qatïg - what else in the world is more cruel than death; The meanings of "strong" and "firm" can be observed (SES, 433). In the Central Asian Interpretation, quality "retains its shape and size under normal conditions" (20.6); "Strong" (27,17); “Difficult, arduous" (27b19); "Which afflicts a man, hurts him" (28,24); Used in "ruthless" (45b7) semaphores. Ahmad Yugnaki in his work gave three meanings to this lexeme:

1) "which retains its shape and size under normal conditions": Baxilğa qatīğ ya oqun kizlägil;

2) “solid": Qazā qaytarïlmas qatï̌ ya qurub;

3) "strong": Qatïğ kizlä rāzïn kiši bilmäsün. In addition, the lexeme was involved in the creation of new words in the epic language: Bu ačun mazasïqatiiğlïğ maza; Aya ranj qatïğsïz sorur umğuči.

2. Words that have expanded in meaning. It is well known that any word is monosemantic when it first appears. However, as a result of continuous development, the meaning of a word can change its semantic structure and become a polysemantic lexeme. Hence, the fact that a lexeme, which originally meant a narrow range of realities, then expresses a wide range of realities is a phenomenon of meaning expansion [8, p. 86]. This process took place due to the shift of a single word in the epic lexicon to polysemantic, its enrichment with colorful new meanings, the expansion of the semantic structure of polysemous words, the formation of portable meanings. Of course, this, in turn, is a testament to the author's skill in using words in their proper place, adding additional meaning to them, giving them appeal. Let us now proceed to the analysis of the examples.

The lexical unit of the Oy, in its monographs, Mahmud Kashgari's Devon, and Turfan's texts, means "the side of the body opposite to the heart" (Ancient Turkic dictionary, 367). The original meaning of the horse is preserved in the "Tafsir": Äwrämiz anlarnï on yan sol yan (1b10). The lexeme was also used in later periods in the senses mentioned. This can be clearly seen in Hibat al-Haqqiq: The Right: Ökünč ol ana yoq on anda azïn; "west”: Ötüb bir-birigä yürür on soya; "beginning": Ol išnin opïnï sojïnï saqïn.

Hence, the first of the mentioned semantics of the word on is denotative, the rest are connotative.

When thinking about the semantics of the kötär//kötür verb in the work, it should be noted that this lexeme is in the form of кӧтӱр (Tafsir, 129,11) in Kultegin's epitaph, "Qutadgu Bilig" and "Devonu Lugotit Turk" (Ancient Turkic dictionary, 320). In the course of our research, we have seen that the verb is used in the epic in the following senses:
a) «to lift »: Niqāb kötrür ačun birär yüz ačar;
б) « to glorify »: Tavāzi' qïlïqnï kötrür izi;
в) «to remove »: Vabāl kötrü bardï üzälä söküš;
г) « to destroy »: Xasislarnïkötrüb nafsnï čalïb.

The lexeme kötär//kötür is formed by adding the suffix $r$ to the köti verb, which means "to move up" in the Old Turkic language, in which $\mathrm{i}$ vowels in the second syllable are replaced by ü vowels, which in turn are replaced by ä vowels, 
and in Uzbek ö vowels are lost: köti-+r- kötir$>$ kötür->kötär-> kötär.

The Kün lexeme "Sun" in the Urhun-Yenisei sources: Kün toğdï qamuğ üzä yaruq boltï - The sun rose and shone in all directions; "Part of the day from sunrise to sunset": Tün künnin qaršïsï ol - night is the opposite of day (SES, 326). In "Kuatdgu Bilig", he means "24 hours": Tiriklik künigä tükäl alqïnur - Life goes on day by day towards nothingness (Ancient Turkic dictionary, 326). In "Devonu Lugotit Turk" it means "Sun", "the part of the day from sunrise to sunset": tün künnün qaršïsï ol - night is the opposite of day (Ancient Turkic dictionary, 326). The language of the epic is used in three senses:

1) "A star that radiates heat and light to the earth": Rasullar örün yüz ol ol yüzrä kün;

2) “Today": Bu kün qazğu saqïnč yarïn yük vabāl;

3) “Everday": Anïn kündä arta turur bu bida'.

In "Tafsir", he writes, "A star that radiates heat and light to the earth" (10b11), "The part of the day from sunrise to sunset" (146.21), "In one of the past and future days" (9.18), (133.11), came in the semantics of "life, life" (70b5).

The semantic word "the part of the journey that is formed as a result of the movement of all things" is given in the footnote:

In Tafsir, he writes, "A star that radiates heat and light to the earth" (10b11), "The part of the day from sunrise to sunset" (146.21), "In one of the past and future days" (9.18), (133.11), came in the semantics of "life, lifetime" (70b5). The semantic word yol means "the part of the journey that is formed as a result of the movement of all things": Kögmän yolï bir ermiš - There is a path in Kokman (SES, 270). In monetary sources, it means "measure of opportunity": Sen üč yolï ïnča teз ayğïl - You tell them about three possible measures
(Ancient Turkic dictionary, 270). In Mahmud Kashgari's "Devonu Lugotit Turk", he expressed the semantics of "way", "way of life, longevity": Ula bolsa yol azmas - If there is a sign, it will not go astray; Yol oğur bolsïn- let it be a good way (Ancient Turkic dictionary, 270). This lexeme is used in four different senses in the study memoir. This, in turn, indicates an expansion of the scope of the word being examined. The term mentioned in the dictionary of the monument means the following semantics:

1) "a long, continuous part formed by the movement of people, animals and other things on the surface of the earth": Kim ol yolluğ ersä anïn yolï yoq;

2) "to travel, to go somewhere, to travel to another place": Ön arqiiš ozadï qopub yol tutub;

3) "way of life”: Bilig birlä bilnür sa'dat yolï;

4) “opportunity": Kim ol yolsuz ersä ana keyrü yol.

In "Hibatul-Hakayik", the köni lexeme have the following meanings: Ağïz til bezägi köni söz turur; "Conscientious, honest, real": Min er dostda biri bulunmas köni; reliable, true friend ": Köni dostun ersä tašï bil munï; "Justice": Köni keltügünčä xayr ketgüük; "To be right": Köni bol köni qïl atïn köni. This word occurs in Yusuf Khos Hajib's epic "Kutadgu Bilig" in the sense of "correct" and "just": Sen utru köni yolqa kirdin...- you have entered the right path opposite (Ancient Turkic dictionary, 315). In Mahmud Kashgari's dictionary it is mentioned in the sema "correct": könier (MK, I, 326). In the vocabulary of the monument, Chinese and Arabic čin and synonyms of truth are also observed: Dad insāf tutar čin anuširvaniy; Majāz boldï dostluq haqiqat qanï; Biligsizgä haq söz tatïqsïz erür. 
The verb tur means "to be", "to live" in the Urhun-Yenisei and Turfon texts: evtä tursa iglig bolur - at home, the disease is observed (Ancient Turkic dictionary, 586) sema. In the work "Devonu Lugotit Turk" "to be in an upright position on one's feet", "to be in a certain place, time, position": ol munda turuğsaq ol - he wanted to stay here, "to live somewhere, to live; to live " ( Ancient Turkic dictionary, 586). Used in the following semantics in "Hibatul Hakoyik":

1) "to be in an upright position on the foot": Anïn kündä arta turur bu bida';

2) "to exist in a place, time, position": Qanï kendü ezgü kiši turğu yer;

3) "to be without expectation, to be, to happen, to be in the hope of coming, to behave for this purpose": Kütüb tur farahqa bala-ranj yütüb;

4) "to move away": Tili yalğan ertin yïraq tur tez-ä;

5) “to absorb ":Serib sendä rāzïn sinib turmasa;

6) “to worship ": Jazā' qïlma ya ranj izisi turub;

7) - dir in place of the cut affix: Ağizz til bezägi köni söz turur.

\section{CONCLUSIONS}

The phenomenon of semantic narrowing observed in the dictionary is a product of the development of society, which is mainly due to the shift of polysemous words to monosemant, the expression of their meaning by other lexemes of their own and assimilated layers, the formation of various new semantics, the development of portable meanings. In addition, the fact that some lexemes used in the early sources of the Old Turkic language and the Old Turkic language are used in a completely different sense in the memoir indicates the uniqueness of the writer's style.

\section{REFERENCES}

1. Khakimova M. Semasiology (2008). Tashkent.-p. 31.

2. Mirtojiev M. Semasiology of Uzbek language (2010) - Tashkent: MUMTOZ SO'Z. - p. 47.

3. Djamalkhanov H. A. Modern Uzbek Literary language. Part II (2004). Tashkent: Tashkent State Pedagogical University. - p. 21.

4. Khakimova M. Semasiology (2008). Tashkent. -p. 67.

5. Mirtojiev M. Semasiology of Uzbek language(2010). - Tashkent: MUMTOZ SO'Z. - p. 113.

6. Examples were retrieved from the materials "About the work "Hibatul haqoyiq" by Ahmad Yugnakiy" written by Kozokboy Mahmudov (Tashkent: Fan, 1972).

7. Davidovich E. A. Materials on the metrology of medieval Central Asia (1970). -Moscow: Nauka. -p. 118.

8. Tursunov U. T., Mukhtorov J., \& Rakhmatullaev Sh. Modern Literary Uzbek language (1992). - Tashkent: Uzbekistan. -p. 86. 